\title{
Habitat heterogeneity influences avian feeding guild composition in urban landscapes: evidence from Bhubaneswar, India
}

\author{
Bibhu Prasad Panda ${ }^{1}$, B. Anjan Kumar Prusty ${ }^{2^{*}}$ (D, Biswajit Panda ${ }^{3}$, Abanti Pradhan ${ }^{1}$ and Siba Prasad Parida ${ }^{4}$
}

\begin{abstract}
Background: Habitat heterogeneity clearly distinguished in terms of availability of food and habitat resources and landscape features (natural or human-modified) play a crucial role in the avian species composition and population structure. To examine this, a study was carried out in Bhubaneswar, India, to understand the ecological niche distinction in birds based on habitat heterogeneity. Regular sampling was conducted in 30 sampling sites covering six different habitat types in a predominantly urban landscape of Bhubaneswar for understanding the ecological niche in birds. The birds were classified into 11 types of foraging guilds.

Results: The insectivorous guild had the highest bird species richness (181 species) and the omnivorous guild had the lowest (11 species). The piscivorous guild and wetland habitat had the strongest linkage, followed by the insectivorous guild and agricultural land. The frugivorous guild was significantly correlated with forest habitats $(r=0.386, p<0.01)$ and park and garden habitats $(r=0.281, p<0.01)$. This urban area hosted a higher number of bird species in certain habitat types, viz., agricultural lands (52\%, 115 species) and forest patches (50\%, 111 species).

Conclusion: The present study highlights the importance of agricultural lands, forest patches, parks and gardens, and wetlands inside the cityscape for supporting avifauna. It is therefore suggested that such habitats should be conserved inside an urban area to protect native avifauna. Thus, the city development plan must invariably include strategies for conserving the forest patches inside the urban area. Measures must be taken to restrain the degradation of agricultural lands and reduce their utilization for non-agricultural purposes, which will help in further reducing the bird population decline in the urban landscape.
\end{abstract}

Keywords: Bird species richness, Community structure, Feeding guild, Habitat characteristics, Urban area

\section{Introduction}

Birds have long been regarded as excellent model systems for studying all biodiversity clans due to their presence in all climatic zones and habitat types (McCain and Grytnes 2010). Although the species diversity and habitat heterogeneity provide information on birds' fundamental spatial ecology, habitat heterogeneity may impact the ecological

\footnotetext{
* Correspondence: anjaneia@gmail.com; bakprusty@khallikoteuniversity.ac.in ${ }^{2}$ Department of Natural Resources Management and Geoinformatics, Khallikote University, Berhampur, Odisha, India

Full list of author information is available at the end of the article
}

processes of birds (Smith et al. 2013; Leveau et al. 2015). Habitat heterogeneity may also have an impact on habitat resources, ultimately determining species diversity and richness in a given area (Lorenzón et al. 2016). A guild, a fundamental concept in avian ecology, is created when a community of birds uses the same class of environmental resources (Balestrieri et al. 2015). All guilds have different tolerance capacities and resource requirements depending on their environment, which is influenced by various factors, viz., food supply, vegetation cover, predator availability, and other factors (Katuwal et al. 2016). As a result,
Springer Open
(๑) The Author(s). 2021 Open Access This article is licensed under a Creative Commons Attribution 4.0 International License, which permits use, sharing, adaptation, distribution and reproduction in any medium or format, as long as you give appropriate credit to the original author(s) and the source, provide a link to the Creative Commons licence, and indicate if changes were made. The images or other third party material in this article are included in the article's Creative Commons licence, unless indicated otherwise in a credit line to the material. If material is not included in the article's Creative Commons licence and your intended use is not permitted by statutory regulation or exceeds the permitted use, you will need to obtain permission directly from the copyright holder. To view a copy of this licence, visit http://creativecommons.org/licenses/by/4.0/. 
different environmental factors affect the avian species assemblage within a particular guild. For example, the birds' feeding guilds are closely associated with habitat and food availability. Thus, Snep et al. (2015) suggest distinguishing the richness gradients for different guilds for a better understanding of the community structure of birds and their habitat selection mechanisms.

The effect of food availability on an organism's population size is a well-known fact in ecological research (de Bonilla et al. 2012). Hence, avian feeding guild studies help to explain (i) the complex ecosystem structure and enhance the existing knowledge about habitats of that particular ecosystem (Rathod and Padate 2017) and (ii) the organization of functional communities and identifying the resources affecting that community structure (Brandl et al. 1994). To create updated data on any avian community structure, birds' feeding patterns must be known (Tanalgo et al. 2015). The dietary habits of birds are analyzed using several techniques, including fecal analysis, gut content analysis, and regurgitated food analysis. Moreover, behavioral observations combined with videographic evidence can substantiate current understandings of that bird species' diet systematics (Lewis et al. 2004). The dietary habits in birds can be affected by habitat conditions/heterogeneity and anthropogenic impacts on their habitat.

Wildlife researchers have focused their ecological investigations on birds and other animal species in natural environments, specially protected areas, rather than urban areas (Ottoni et al. 2009). Under the tremendous pressures of urbanization, the native habitats of birds have been lost, fragmented, or modified, with the native vegetation altered to a large extent (McKinney 2008; Leveau et al. 2020). Meanwhile, urban areas with fragmented and patchy habitats can still support a high level of biodiversity, especially in their woodlands and wetlands (Panda et al. 2020). Nonetheless, plentiful untapped resources such as food, shelter, nesting sites and breeding areas seem to draw birds to urbanized areas (Čanády and Mošanský 2017). Urban areas, with their concrete structures, recreational parks, and private property gardens, provide breeding and roosting habitats for birds as well as additional food resources (Ottoni et al. 2009). In urban areas, where the presence of several smaller habitats and feeding guilds is greater, a rich diversity of birds can be seen (Leveau and Leveau 2016). On the other hand, diversity can be minimum where the urban structure is highly developed, with very little vegetation (Donnelly and Marzluff 2004; Leveau and Leveau 2020). Given these specifics, the present study was carried out to examine the influence of habitat heterogeneity (represented by small and patchy habitats in a human-modified urban landscape) on bird species diversity, richness, and feeding guild.

\section{Methods}

\section{Study area}

The present study was conducted in the urban landscape of Bhubaneswar (Fig. 1), the capital of Odisha state in India. Bhubaneswar has a tropical climate and is located at $45 \mathrm{~m}$ asl. The average annual temperature is $27.4{ }^{\circ} \mathrm{C}$ and the annual rainfall is $1505 \mathrm{~mm}$. The municipal area is spread over approximately $419 \mathrm{~km}^{2}$, and the city's landscape consists of diverse habitats such as urban forests and woodlands as well as highly urbanized residential and commercial complexes. The city has around 10 large wetlands ( $>2.25 \mathrm{ha}$ ), more than 50 small wetlands $(<2.25 \mathrm{ha})$, and the River Daya flowing along the eastern part of the city. Besides the urban green spaces and woodlands, the city has over 120 parks and many green spaces that are known to support urban biodiversity (Nair 2014), including human habitation, agricultural lands, grasslands, and parks/gardens. The present study was conducted in six different habitats: (i) grassland (GL): large grass fields are found that have fewer herbs and shrubs, (ii) wetland (WL): large water bodies and swampy area, (iii) forest patch (FP): dense woody vegetation with a high density of trees, (iv) park and garden (PG): scrublands and manmade gardens with human interference, (v) agricultural land (AL): farmlands and crop fields inside the city, and (vi) human habitation $(\mathrm{HH})$ : residential colonies and urban structures with high human disturbance. In the present study, for regular bird surveys, five sites were randomly selected in each of these six habitat types, totaling 30 sampling sites (Table 1).

\section{Sampling}

Bird surveys and associated samplings were carried out during March 2016 through February 2017, to observe and record birds following the distance point count technique of Bibby et al. (1998). The survey was conducted in each of the 30 sites in every alternative month over the year (Leveau et al. 2015), i.e., six times each in 30 sampling sites for a total of 180 samplings. The geocoordinates of locations were recorded using a handheld GPS (Garmin etrex10, Heather and Robertson 2000). Monthly 1-day surveys were conducted with 2-3 welltrained observers in each site for $4 \mathrm{~h}$ after sunrise and 2 $\mathrm{h}$ before sunset (Leveau et al. 2015). In total, $72 \mathrm{~h}$ were spent at each site, with a total of $2160 \mathrm{~h}$ of effort put in for the entire survey in the present study. Surveys were not conducted during inclement weather (rain or strong winds, Pan et al. 2008). The present survey covered summer (March-June), rainy (July-October) and winter (November-February) seasons. Behavioral observations were recorded manually to generate data on birds' feeding guild throughout the year. The levels of disturbance in and around each of the sampling sites were also 


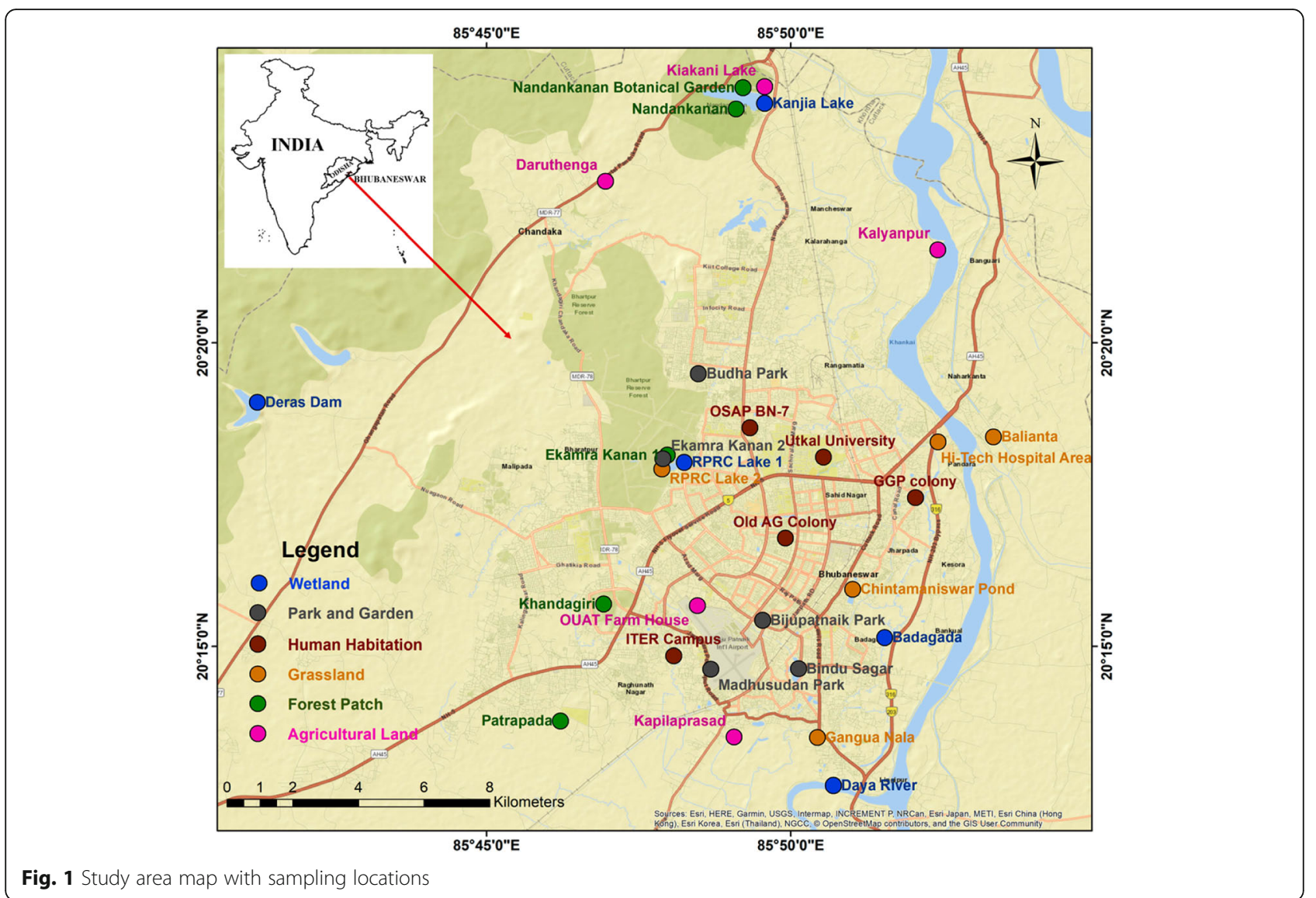

recorded (Rajashekara and Venkatesha 2015, 2017, 2018; Čanády and Mošanský 2017) and noted for further interpretation.

\section{Guild classifications}

Based on their diet and foraging habitat, the bird species were grouped into various feeding guilds (DeGraaf et al. 1985; Gray et al. 2007; Prajapati and Prajapati 2013; Ding et al. 2019). In the present study, 11 different guilds were identified (Table 2). In each of the sampling locations, species richness was evaluated for each of the observed feeding guilds.

\section{Data analysis}

The birds observed in the area were classified into orders and families with habitat preferences based on their occurrences in various habitats (WL, AL, PG, FP, HH, and GL). For each habitat, the Shannon-Wiener diversity index was determined to understand the avian species' preference for each of the sites and habitats. The independent percentage contribution for every guild from each habitat was calculated as under:

$100 \times$ (number of species of the guild $i$ in habitat $j /$ total number of species in habitat $j$ ) (de Bonilla et al. 2012).
The significant difference in the habitats and feeding guilds with respect to the species richness was tested using one-way analysis of variance (ANOVA). The BrayCurtis similarity index was employed to investigate the variations in bird species composition using the adonis function of the vegan package in $\mathrm{R}$ (Oksanen et al. 2015). Hierarchical cluster analysis with matrix plot was used to examine the distribution of bird species across habitats and the habitat preferences of different species. Pearson's correlation test was employed to determine the commonness of avian richness and feeding guild among different urban habitats using corr-plot in the $\mathrm{R}$ version 3.4.4 (RStudio 2013). The bird species occurrence according to the feeding guild was considered as the independent variable, while all of the feeding guilds were considered dependent variables. All these different types of analysis were used to give quantitative direction to the work. All the statistical tests were done at $a=$ 0.05 level of significance.

\section{Results}

In total, 222 bird species belonging to 19 orders and 65 families were recorded in and around Bhubaneswar city, which differed significantly among the habitats $(F=2.69$, $p<0.01)$. Among the habitats, agricultural habitat was 
Table 1 A snapshot of sampling sites

\begin{tabular}{|c|c|c|c|c|}
\hline $\begin{array}{l}\text { SI } \\
\text { no. }\end{array}$ & Place & Habitat & Sampling site details & $\begin{array}{l}\text { Level of } \\
\text { disturbance }\end{array}$ \\
\hline 1 & Ekamra Kanan 1 & $\mathrm{FP}$ & One part of the reserve forest and undisturbed area & Low \\
\hline 2 & Khandagiri & FP & Undisturbed area but near to road and tourist spot & Moderate \\
\hline 3 & Patrapada & $\mathrm{FP}$ & Undisturbed area surrounded by shrubland & Low \\
\hline 4 & $\begin{array}{l}\text { Nandankanan Botanical } \\
\text { Garden }\end{array}$ & $\mathrm{FP}$ & One part of wildlife sanctuary area but open for public & Moderate \\
\hline 5 & Nandankanan & $\mathrm{FP}$ & Zoological park and wildlife sanctuary & High \\
\hline 6 & Kapilaprasad & $A L$ & Agricultural land near to a road & Moderate \\
\hline 7 & Kalyanpur & $A L$ & Agricultural land near a river & Low \\
\hline 8 & Kiakani Lake & $\mathrm{AL}$ & Agricultural field near a small industrial area & Moderate \\
\hline 9 & Daruthenga & $A L$ & Agricultural fields near the village & Low \\
\hline 10 & OUAT Farm House & $\mathrm{AL}$ & Agricultural fields near the airport and inside the university campus & Low \\
\hline 11 & RPRC Lake 2 & GL & Grassland near wetland & Low \\
\hline 12 & Gangua Nala & GL & Grassland near a polluted water channel & Moderate \\
\hline 13 & Hi-tech Hospital Area & GL & Undisturbed grassland near a riverbank & Low \\
\hline 14 & Balianta & $\mathrm{GL}$ & Grassland near river and village & Moderate \\
\hline 15 & Chintamaniswar Pond & $\mathrm{GL}$ & Grassland near pond surrounded by human habitation & Moderate \\
\hline 16 & ITER Campus & $\mathrm{HH}$ & Human habitation with high urban structure & High \\
\hline 17 & OSAP BN-7 & $\mathrm{HH}$ & Human habitation with moderate canopy cover & High \\
\hline 18 & Utkal University & $\mathrm{HH}$ & Human habitation but with a large canopy cover & High \\
\hline 19 & Old AG Colony & $\mathrm{HH}$ & Human habitation with high population density & High \\
\hline 20 & GGP Colony & $\mathrm{HH}$ & Human habitation with high population density & High \\
\hline 21 & Ekamra Kanan 2 & $P G$ & Park area connected with a reserve forest & High \\
\hline 22 & Madhusudan Park & PG & Park area beside the airport & High \\
\hline 23 & Budha Park & $P G$ & Park area near human habitation & High \\
\hline 24 & Bindu Sagar & PG & Park area near human habitation and pilgrimage site & High \\
\hline 25 & Biju Patnaik Park & $P G$ & Park area near hospital and surrounded by human habitation & High \\
\hline 26 & RPRC Lake 1 & WL & Wetland near park area and small office complexes & Moderate \\
\hline 27 & Badagada & WL & Wetland near highway & Moderate \\
\hline 28 & Kanjia Lake & WL & Wetland near a wildlife sanctuary area & Low \\
\hline 29 & Deras Dam & WL & $\begin{array}{l}\text { Wetland and dam area surrounded by reserve forest and one part open as a } \\
\text { tourist spot }\end{array}$ & Low \\
\hline 30 & Daya River & WL & Riverine ecosystem near the peripheral city & Low \\
\hline
\end{tabular}

GL grassland, $W L$ wetland, $F P$ forest patch, $P G$ park and garden, $A L$ agricultural land, $H H$ human habitation

found to be species-rich (52\%, 115 species) and human habitation as species-poor habitat $(8 \%, 17$ species). The order of habitats in terms of species richness is $\mathrm{AL}(52 \%$, 115 species $)>$ FP $(50 \%, 111$ species $)>$ PG $(39 \%, 87$ species) $>$ WL $(32 \%, 70$ species $)>$ GL $(11 \%, 24$ species $)>$ $\mathrm{HH}(8 \%, 17$ species) of the total species richness (Table 3). Further, the number of species in each guild, along with the number of individuals observed in that particular guild, is presented in Fig. 2. It was observed that, in a particular feeding guild, if the number of species was higher, then the number of individuals was also higher. Among the feeding guilds, insectivore was the guild with the highest number of species (181 species) and omnivore was the guild with the least number of species (11 species), and the observed order was insectivorous $>$ frugivorous $>$ granivorous $>$ piscivorous $>$ molluscivorous $>$ carnivorous $>$ nectarivorous $>$ avivorous $>$ ophiophagus $>$ herbivorous $>$ omnivorous (Fig. 2, Table 3). The feeding guilds differed significantly for the number of bird species $(F=2.61, p<0.01)$. Irrespective of the habitats, the insectivorous guild was represented with a maximum number of species and thereby remained as a dominant one among all the guilds. The comparison of the abundance of species from all habitats within every feeding guild can be shown in Table 3 . The Shannon-Wiener diversity index in different habitats was 
Table 2 Classification of avian feeding guild based on predominant diet

\begin{tabular}{lll}
\hline Feeding guild & Category & Food source \\
\hline Frugivorous & Frugivore, fruit eater & Fleshy fruits \\
Carnivorous & Carnivore, raptor, predator & Large arthropods and vertebrate prey \\
Avivorous & Avivour, egg stealer & Birds \\
Granivorous & Granivore, seed eater & Grain, seeds, and nuts \\
Insectivorous & Insectivore, ant follower, woodpecker & Small arthropods \\
Molluscivorous & Molluscivore & Molluscs \\
Nectarivorous & Nectarivore, pollen eater & Nectar \\
Ophiophagous & Ophiophagus, reptile eater & Snake \\
Piscivorous & Piscivore & Fishes \\
Omnivorous & Omnivore, miscellaneous (animals and plant parts) & Plant (grain, seed, leaf, stem, root) and animal (insect, mollusc, fish, etc.) \\
Herbivorous & Herbivore, plant eater & Herbs and macrophytes (stem and roots) \\
\hline
\end{tabular}

in the order forest patch (4.421) > agricultural land (4.415) > park and garden (4.173) > wetland (3.772) > grassland (2.693) > human habitation (2.615).

These diverse habitats may affect bird feeding guilds, but specific habitats such as agricultural land were found to support the highest species richness of the insectivorous birds. The scatter plot of all the guilds, comparing all birds, is described to show the composition of the abundance of each species in each guild. An asymmetric pattern in the abundance of bird species in each guild was seen in this study area. The insectivorous guild was found to have an abundance-rich pattern in the scatter plot analysis (Fig. 3).

The Pearson correlation coefficient provided insights on the specific preference of bird species under one foraging guild towards a particular habitat (Fig. 4). The

Table 3 Species presence at all habitats of each feeding guild

\begin{tabular}{|c|c|c|c|c|c|c|c|}
\hline \multirow[t]{2}{*}{ Feeding guilds } & \multicolumn{6}{|c|}{ Habitats } & \multirow{2}{*}{$\begin{array}{l}\text { No. of } \\
\text { species }\end{array}$} \\
\hline & $\overline{W L}$ & FP & PG & $A L$ & $\mathrm{HH}$ & $\mathrm{GL}$ & \\
\hline Frugivorous & 3 & 41 & 32 & 28 & 10 & 4 & 50 \\
\hline Carnivorous & 9 & 16 & 13 & 11 & 2 & 3 & 29 \\
\hline Avivorous & 8 & 12 & 9 & 8 & 1 & 1 & 20 \\
\hline Granivorous & 4 & 23 & 16 & 31 & 5 & 4 & 43 \\
\hline Insectivorous & 58 & 87 & 68 & 95 & 11 & 24 & 181 \\
\hline Molluscivorous & 27 & 5 & 4 & 12 & 0 & 4 & 33 \\
\hline Nectarivorous & 0 & 21 & 12 & 9 & 2 & 4 & 22 \\
\hline Ophiophagous & 4 & 15 & 11 & 11 & 2 & 1 & 20 \\
\hline Piscivorous & 32 & 6 & 5 & 15 & 0 & 2 & 38 \\
\hline Omnivorous & 3 & 8 & 4 & 6 & 3 & 0 & 11 \\
\hline Herbivorous & 6 & 4 & 2 & 6 & 0 & 1 & 13 \\
\hline No. of species & 70 & 111 & 87 & 115 & 17 & 24 & \\
\hline
\end{tabular}

GL grassland, $W L$ wetland, FP forest patch, $P G$ park and garden, $A L$ agricultural land, $H H$ human habitation frugivorous guild was significantly correlated with the forest patch habitat $(r=0.386, p<0.01)$, park and garden habitat $(r=0.281, p<0.01)$, and human habitation $(r=0.284, p<0.01)$. The granivorous birds were strongly associated with agricultural habitat $(r=0.209, p$ $<0.01)$. The birds seen in the insectivorous guild were strongly associated with grassland habitat $(r=0.168, p<$ $0.05)$. The wetland habitats were strongly associated with birds in the molluscivorous guild $(r=0.452, p<0.01)$ and the piscivorous guild $(r=0.515, p<0.01)$. A significant positive correlation was found between the nectarivorous guild and forest habitat $(r=0.292, p<0.01)$. The birds seen in the omnivorous guild were significantly associated with human habitation $(r=0.168, p<$ 0.05 , Fig. 4). On the whole, the feeding guild of birds was a function of the habitat.

\section{Discussion}

The patterns of feeding behavior in birds recorded in the present study indicate both the generalist and the specialist nature of birds in the area. Urbanized landscapes with wider habitat differences are known to create an ecosystem for the insectivorous-rich bird community (Gray et al. 2007; de Bonilla et al. 2012; Ding et al. 2019). In agreement with the extant literature (Rajpar and Zakaria 2011), the feeding behavior of bird species' was in sync with their habitat, which reflected the extent of resource use in that particular habitat. The similarity among all the different habitats and feeding guilds was observed during the present study (Fig. 5), in the form of a dendrogram of similarity index. The most similar cluster is formed between the carnivorous and the avivorous species, indicating that the bird species which feed on birds might also feed on other animals (Sohil and Sharma 2020). In Fig. 5, the omnivorous birds are placed close to human habitation (represented by less 


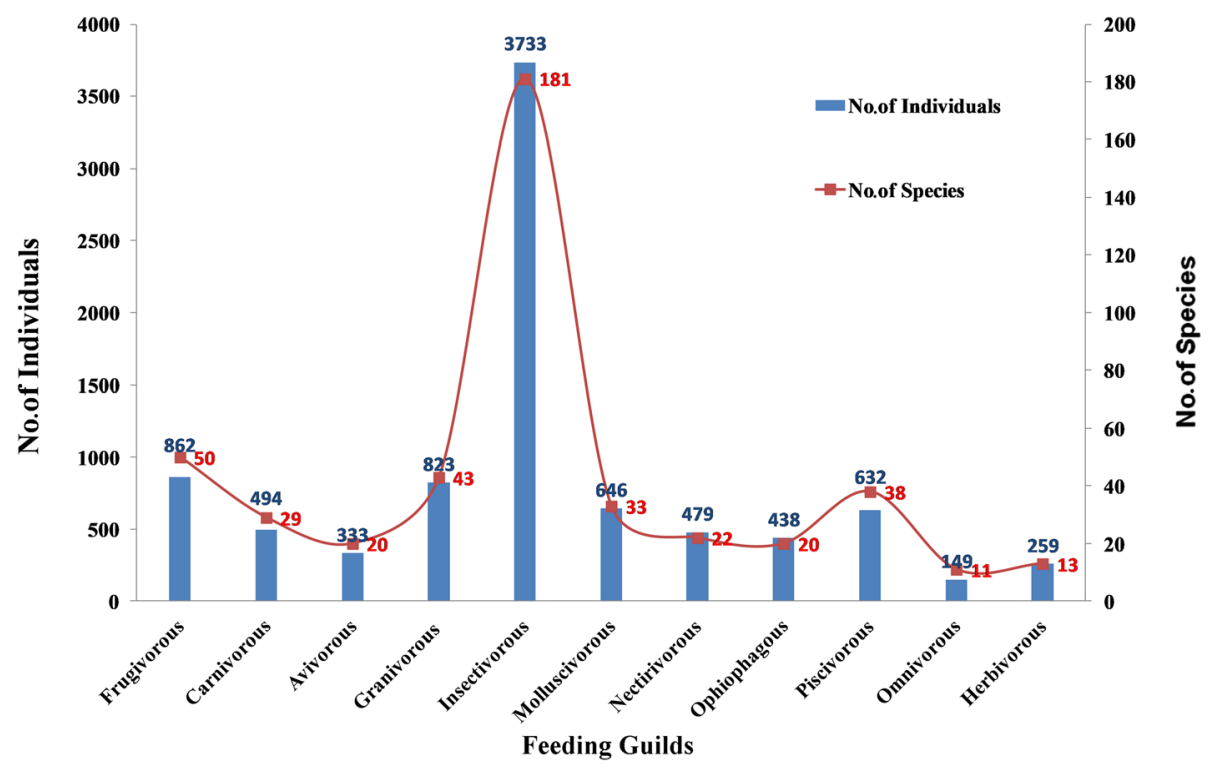

Fig. 2 Species and individual occurrence of birds in different feeding guilds

Euclidean distance from each other), which is suggestive of the fact that the human habitation in urban areas might be a source of various feeding objects for birds. In conforming to earlier studies (Ottoni et al. 2009; Mukhopadhyay and Mazumdar 2017, 2019), the omnivorous birds were largely found in humandominated landscapes and residential areas. In another cluster, the piscivorous and the molluscivorous birds have less Euclidean distance from the wetland habitat. It is known that the abundance of fishes and molluscs is high in wetland habitats, which attracts the wetland birds that are mainly dependent on these organisms for their food (Prajapati and Prajapati 2013; Panda et al. 2021). The frugivorous and the granivorous guilds are in one cluster, which is suggestive of the fact that the fruit-eating birds are mostly grain-eating species that share nearly the same habitat, in the ecosystem like forest and farmlands nearby (Mulwa et al. 2012). The forest patch and park and garden habitats were seen forming one cluster, as these two types of habitats comprise mostly woody vegetation where similar species occurrence is found (Leveau et al. 2019; Wielstra et al. 2011). In line with our expectations, agricultural habitat and the insectivorous feeding guild were found to be clustered together in similarity index. The agricultural lands are rich in insect diversity, thereby attracting the insectivorous birds as an easy foraging ground (Munira et al. 2011).

Bird populations in various fragmented forest landscapes generally respond to these urban-influenced complex environmental combinations in a resilient manner (Leveau 2019, 2021). Birds are not only dependent on the habitat's resources; the ecosystem's functional viability may also be dependent on the ecological processes provided by these organisms (Gray et al. 2007). Naturally, some bird species are known to be associated with more than one habitat type (Lorenzón et al. 2016), and the presence of the same species in different habitats indicates that resource conditions are met effectively in both natural and human-modified habitats, such as agricultural lands. In the urbanized landscape of Bhubaneswar, the insectivorous feeding guild was found to be the most common, followed by the frugivorous and the granivorous. The mixed habitat of this human-modified landscape might have culminated in an insect-rich habitat, thereby the diversity of the insectivorous guild is higher (Tanalgo et al. 2015). However, due to the lack of suitable soil moisture conditions in highly urbanized habitats, the insectivorous guild seemed to have been severely affected. Because of the availability of a variety of food sources, the omnivorous-rich bird population thrived well in the human-altered landscapes, especially human habitations and residential colonies. Studies carried out elsewhere (Ottoni et al. 2009; de Bonilla et al. 2012) are also in agreement with the present findings. In the present study, both the frugivorous and the omnivorous guilds were found to have been positively influenced by both the food resource availability and suitability. The habitat heterogeneity causes significant differences in species richness in specific feeding guilds, viz., the insectivorous and the frugivorous supported by specific habitats like agricultural land and forest habitats, respectively. Major factors such as productivity, disturbance, and habitat heterogeneity may influence local species richness patterns (Lorenzón et al. 2016). Thus, investigations on habitat-specific species 


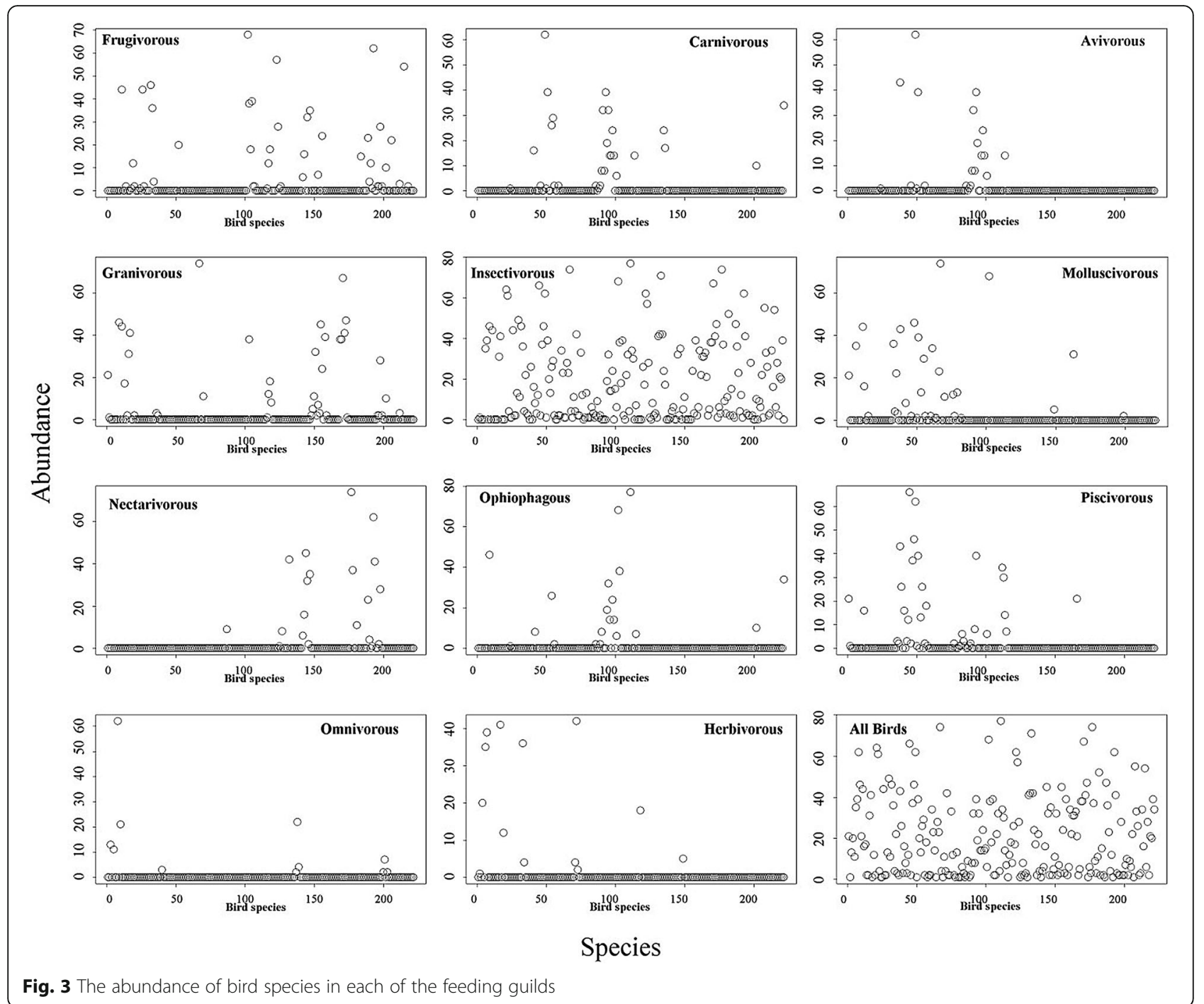

abundances of birds are essential to understand the exact functional relationship. Such functional relationships are manifested in terms of feeding habits of birds, as investigated in the present study, thereby corroborating the hypothesis that feeding guilds in birds can be a function of the habitat. This, in turn, is linked with resource availability in a particular habitat.

\section{Conclusions}

The present study is an attempt to create a database on habitat-wise species richness and abundance of birds according to their feeding guild and is the first of its kind study on bird-habitat-feeding guild relationship in an urbanized landscape of Bhubaneswar. The urban landscape of Bhubaneswar supports a good number of bird species, which is a promising factor for furthering the ornithological research in the region. Agricultural lands, forest patches, parks and gardens, and wetlands inside the cityscape served as the food base for the birds and seemed to have supported a maximum number of bird species. Thus, the creation of small parks and other green patches inside the urban structures can help in promoting bird diversity in the cityscape. The highly modified urban structures supported only a few species of birds, especially the omnivorous ones and those dependent on human habitations. The insectivorous guild being the species-rich feeding guild demonstrated the importance of agricultural landscape in and around the urban area. The urbanized landscapes with diversified habitats support birds under specific feeding guilds as a function of habitat quality and resource (e.g., food) availability. The findings of the study necessitate creating woody habitats and controlling the degradation of agricultural lands for long-term maintenance of such diversity-rich habitats. That is to say the avian affinity structure as a part of urban planning and associated policy frameworks are recommended. 


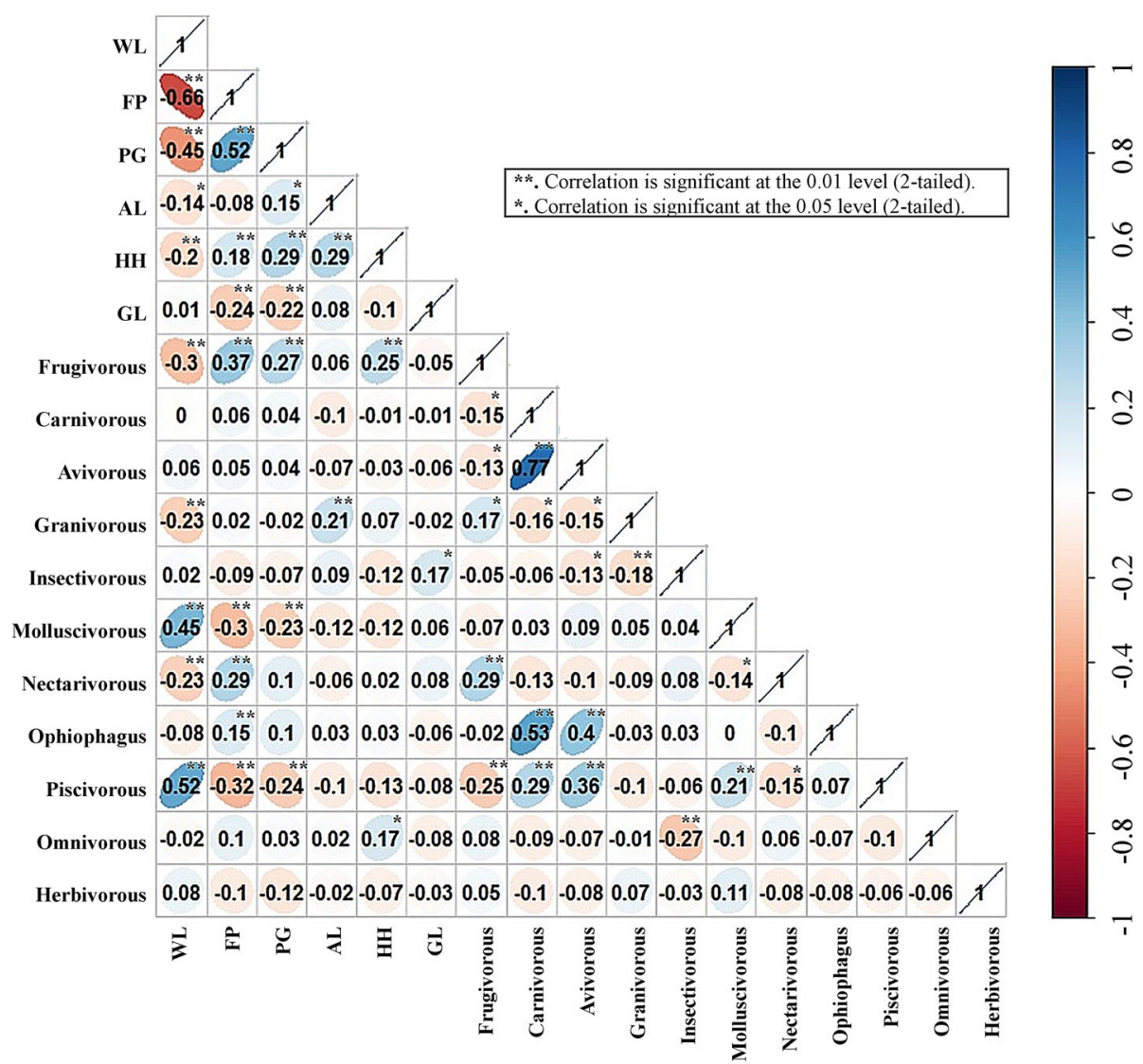

Fig. 4 Corr-plot showing correlations among habitats and feeding guilds concerning bird species abundance. GL grassland, WL wetland, FP forest patch, $P G$ park and garden, AL agricultural land, HH human habitation

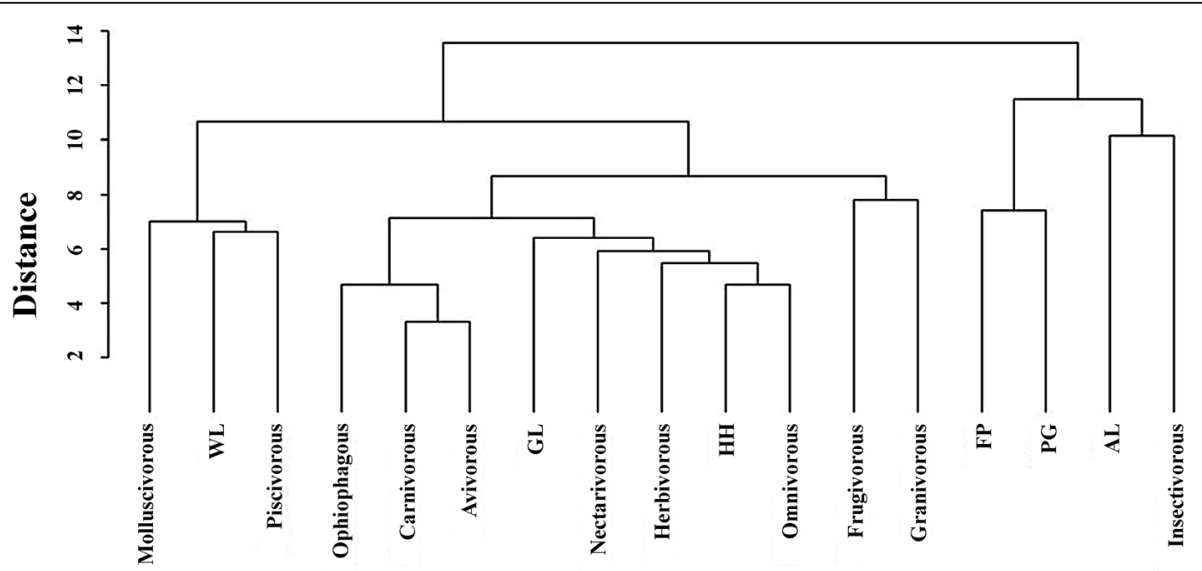

\section{Feeding Guilds and Habitats}

Fig. 5 Hierarchical cluster of feeding guilds and habitats for bird species abundance. GL grassland, WL wetland, FP forest patch, PG park and garden, AL agricultural land, HH human habitation 


\section{Abbreviations}

AL: Agricultural land; ANOVA: Analysis of variance; FP: Forest patch; GL: Grassland; HH: Human habitation; PG: Park and garden; WL: Wetland

\section{Supplementary Information}

The online version contains supplementary material available at https://doi. org/10.1186/s13717-021-00304-6

\section{Additional file 1}

\section{Acknowledgements}

The authors thankfully acknowledge the persons who helped with the completion of the fieldwork. We are thankful to the Department of Forest and Environment, Govt. of Odisha, for according necessary permissions to carry out the survey. We are grateful to the two anonymous reviewers for offering their valuable comments, which helped in improvising the manuscript.

\section{Authors' contributions}

BPP conceptualized the study and collected the data along with BP. BPP analyzed the data and wrote the manuscript. BAKP supervised the whole study and finalized the manuscript. AP and SPP edited the manuscript. The authors read and approved the final manuscript.

\section{Funding}

The study is self-financed.

\section{Availability of data and materials}

Not applicable

\section{Declarations}

\section{Ethics approval and consent to participate}

All requisite information and data were collected without disturbing the birds and their habitats. Photographic recordings were made using a telephoto lens.

\section{Consent for publication}

Not applicable

\section{Competing interests}

The authors declare that they have no competing interests.

\section{Author details}

'Environmental Sciences, Department of Chemistry and BBRC, ITER, Siksha 'O' Anusandhan (Deemed to be University), Bhubaneswar, Odisha, India. 2Department of Natural Resources Management and Geoinformatics, Khallikote University, Berhampur, Odisha, India. ${ }^{3}$ Department of Stem Cell Facility, All India Institute of Medical Sciences, New Delhi, India. ${ }^{4}$ Department of Zoology, School of Applied Sciences, Centurion University of Technology and Management, Bhubaneswar, Odisha, India.

Received: 5 March 2021 Accepted: 21 April 2021

Published online: 10 May 2021

\section{References}

Balestrieri R, Basile M, Posillico M, Altea T, de Cinti B, Matteucci G (2015) A guildbased approach to assessing the influence of beech forest structure on bird communities. For Ecol Manage 356:216-223. https://doi.org/10.1016/j.foreco.2 015.07.011

Bibby C, Martin J, Stuart M (1998) Expedition field techniques, bird surveys. Expedition Advisory Center, Royal Geographical Society, London

Brandl R, Kristín A, Leisler B (1994) Dietary niche breadth in a local community of passerine birds: an analysis using phylogenetic contrasts. Oecologia 98(1): 109-116. https://doi.org/10.1007/BF00326096

Čanády A, Mošanský L (2017) Public Cemetery as a biodiversity hotspot for birds and mammals in the urban environment of Kosice city (Slovakia). Zool Ecol 27(3-4):185-195. https://doi.org/10.1080/21658005.2017.1366024 de Bonilla EPD, León-Cortés JL, Rangel-Salazar JL (2012) Diversity of bird feeding guilds in relation to habitat heterogeneity and land-use cover in a humanmodified landscape in southern Mexico. J Trop Ecol 28(4):369-376. https:// doi.org/10.1017/S026646741200034X

DeGraaf RM, Tilghman NG, Anderson SH (1985) Foraging guilds of North American birds. Environ Manage 9(6):493-536

Ding Z, Liang J, Hu Y, Zhou Z, Sun H, Liu L, Liu H, Hu H, Si X (2019) Different responses of avian feeding guilds to spatial and environmental factors across an elevation gradient in the central Himalaya. Ecol Evol 9(7):1-13. https://doi. org/10.1002/ece3.5040

Donnelly R, Marzluff JM (2004) Importance of reserve size and landscape context to urban bird conservation. Conserv Biol 18(3):733-745. https://doi.org/1 0.1111/j.1523-1739.2004.00032.x

Gray MA, Baldauf SL, Mayhew PJ, Hill JK (2007) The response of avian feeding guilds to tropical forest disturbance. Conserv Biol 21(1):133-141. https://doi. org/10.1111/j.1523-1739.2006.00557.x

Heather BD, Robertson HA (2000) The field guide to the birds of New Zealand. Viking, Auckland

Katuwal HB, Basnet K, Khanal B, Devkota S, Rai SK, Gajurel JP, Scheidegger C, Nobis MP (2016) Seasonal changes in bird species and feeding guilds along elevational gradients of the Central Himalayas, Nepal. PLoS One 11(7): e0158362. https://doi.org/10.1371/journal.pone.0158362

Leveau LM (2019) Urbanization induces bird color homogenization. Landsc Urban Plan 192:103645. https://doi.org/10.1016/j.landurbplan.2019.103645

Leveau LM (2021) Big cities with small green areas hold a lower proportion of migrant birds: a global analysis. Urban For Urban Green 57:126953. https:// doi.org/10.1016/j.ufug.2020.126953

Leveau LM, Leveau CM (2016) Does urbanization affect the seasonal dynamics of bird communities in urban parks? Urban Ecosyst 19(2):631-647. https://doi. org/10.1007/s11252-016-0525-5

Leveau LM, Leveau CM (2020) Street design in suburban areas and its impact on bird communities: considering different diversity facets over the year. Urban For Urban Green 48:126578. https://doi.org/10.1016/j.ufug.2019.126578

Leveau LM, Isla Fl, Bellocq MI (2015) Urbanization and the temporal homogenization of bird communities: a case study in central Argentina. Urban Ecosyst 18(4):1461-1476. https://doi.org/10.1007/s112 52-015-0469-1

Leveau LM, Ruggiero A, Matthews TJ, Bellocq MI (2019) A global consistent positive effect of urban green area size on bird richness. Avian Res 10(1):30, https://doi.org/10.1186/s40657-019-0168-3

Leveau LM, Isla Fl, Bellocq MI (2020) From town to town: predicting the taxonomic, functional and phylogenetic diversity of birds using NDVI. Ecol Indic 119:106703. https://doi.org/10.1016/j.ecolind.2020.106703

Lewis SB, Fuller MR, Titus K (2004) A comparison of 3 methods for assessing raptor diet during the breeding season. Wildl Soc Bull 32(2):373-385. https:// doi.org/10.2193/0091-7648(2004)32[373:acomfa]2.0.co;2

Lorenzón RE, Beltzer AH, Olguin PF, Ronchi-Virgolini AL (2016) Habitat heterogeneity drives bird species richness, nestedness and habitat selection by individual species in fluvial wetlands of the Paraná River, Argentina. Austral Ecol 41(7):829-841. https://doi.org/10.1111/aec.12375

McCain CM, Grytnes J-A (2010) Elevational gradients in species richness. Encycl Life Sci:1-10. https://doi.org/10.1002/9780470015902.a0022548

McKinney ML (2008) Effects of urbanization on species richness: a review of plants and animals. Urban Ecosyst 11(2):161-176. https://doi.org/10.1007/s112 52-007-0045-4

Mukhopadhyay S, Mazumdar S (2017) Composition, diversity and foraging guilds of avifauna in a suburban area of southern West Bengal, India. The Ring 39(1):103-120. https://doi.org/10.1515/ring-2017-0004

Mukhopadhyay S, Mazumdar S (2019) Habitat-wise composition and foraging guilds of avian community in a suburban landscape of lower Gangetic plains, West Bengal, India. Biologia 74(8):1001-1010. https://doi.org/10.2478/ s11756-019-00226-X

Mulwa RK, Neuschulz EL, Böhning-Gaese K, Schleuning M (2012) Seasonal fluctuations of resource abundance and avian feeding guilds across forestfarmland boundaries in tropical Africa. Oikos 122(4):1-9. https://doi.org/1 0.1111/j.1600-0706.2012.20640.x

Munira A, Salmi AL, Anuar MS (2011) Avian diversity and feeding guilds in a secondary forest, an oil palm plantation and a paddy field in Riparian Areas of the Kerian River Basin, Perak, Malaysia. Trop Life Sci Res 22:45-64. https:// doi.org/10.1007/s13398-014-0173-7.2

Nair A (2014) The Bhubaneswar bird walks. Sanctuary Asia 34(6):86-87 
Oksanen J, Blanchet FG, Kindt R et al (2015) Vegan: community ecology package. $R$ package version 2.0-10

Ottoni I, de Oliveira FFR, Young RJ (2009) Estimating the diet of urban birds: the problems of anthropogenic food and food digestibility. Appl Anim Behav Sci 117(1-2):42-46. https://doi.org/10.1016/j.applanim.2008.11.002

Pan C, Zheng G, Zhang Y (2008) Concentrations of metals in liver, muscle and feathers of tree sparrow: age, inter-clutch variability, gender, and species differences. Bull Environ Contam Toxicol 81(6):558-560. https://doi.org/10.1 007/s00128-007-9168-9

Panda BP, Mahapatra B, Sahoo AA et al (2020) Habitat use of urban and periurban birds in a densely populated city of Eastern India. Asia J Conserv Biol 9:290-297

Panda BP, Das AK, Jena SK, Mahapatra B, Dash AK, Pradhan A, Parida SP (2021) Habitat heterogeneity and seasonal variations influencing avian community structure in wetlands. J Asia-Paci Biodiver 14(1):23-32. https://doi.org/10.101 6/j.japb.2020.10.001

Prajapati SH, Prajapati RP (2013) Classified guilds in avian community with respect to food and feeding behaviour. Indian J Sci Res Technol 1:1-7

Rajashekara S, Venkatesha MG (2015) Temporal and spatial avian community composition in urban landscapes of the Bengaluru region, India. J Environ Biol 36:607-616

Rajashekara S, Venkatesha MG (2017) Seasonal incidence and diversity pattern of avian communities in the Bangalore University Campus, India. Proc Zool Soc 70(2):178-193. https://doi.org/10.1007/s12595-016-0175-x

Rajashekara S, Venkatesha MG (2018) Impact of urban threats and disturbance on the survival of waterbird communities in wetlands of Bengaluru City, India. Proc Zool Soc 71(4):336-351. https://doi.org/10.1007/s12595-017-0217-z

Rajpar MN, Zakaria M (2011) Bird species abundance and their correlationship with microclimate and habitat variables at natural wetland reserve, peninsular Malaysia. Int J Zool 2011:758573-758517. https://doi.org/10.1155/2 011/758573

Rathod J, Padate G (2017) Feeding guilds of urban birds of Vadodara city. Int J Fauna Biol Stud 4:78-85

RStudio (2013) R: a language and environment for statistical computing. Smith AC, Francis CM, Fahrig L (2013) Similar effects of residential and nonresidential vegetation on bird diversity in suburban neighbourhoods. Urban Ecosyst 17(1):27-44. https://doi.org/10.1007/s11252-013-0301-8

Snep RPH, Kooijmans JL, Kwak RGM, Foppen RPB, Parsons H, Awasthy M, Sierdsema HLK, Marzluff JM, Fernandez-Juricic E, de Laet J, van Heezik YM (2015) Urban bird conservation: presenting stakeholder-specific arguments for the development of bird-friendly cities. Urban Ecosyst 19(4):1535-1550. https://doi.org/10.1007/s11252-015-0442-z

Sohil A, Sharma N (2020) Assessing the bird guild patterns in heterogeneous land use types around Jammu, Jammu and Kashmir, India. Ecol Process 9:49. https://doi.org/10.1186/s13717-020-00250-9

Tanalgo KC, Pineda JAF, Agravante ME, Amerol ZM (2015) Bird diversity and structure in different land-use types in lowland south-central Mindanao, Philippines. Trop Life Sci Res 26(2):85-103

Wielstra B, Boorsma T, Pieterse SM, de longh HH (2011) The use of avian feeding guilds to detect small-scale forest disturbance: a case study in East Kalimantan, Borneo. Forktail 27:55-62

\section{Publisher's Note}

Springer Nature remains neutral with regard to jurisdictional claims in published maps and institutional affiliations.

\section{Submit your manuscript to a SpringerOpen ${ }^{\circ}$ journal and benefit from:}

- Convenient online submission

- Rigorous peer review

- Open access: articles freely available online

- High visibility within the field

- Retaining the copyright to your article

Submit your next manuscript at $\boldsymbol{\nabla}$ springeropen.com 